\title{
Aplikasi Penjualan Kelapa Sawit Berbasis Web pada KUD di Kab. Dharmasraya
}

\author{
Rhiyan Edyal, Bintang Eka Putra \\ Jurusan Sistem Ko mputer \\ Fakultas Ilmu Ko mputer dan Teknologi Informasi \\ Universitas Gunadarma \\ Jl. Margonda Raya No. 100 Depok. \\ rhiyan85@g mail.com, bintang.ep@staff.gunadarma.ac.id
}

Diterima: 11 September 2016. Disetujui: 25 Oktober 2016. Dipublikasikan: Nope mber 2016

\begin{abstract}
Abstrak - Penelitian ini bertujuan untuk memberikan gambaran tentang bagaimana proses penjualan kelapa sawit di tingkat petani serta pembuatan aplikasi penjualan kelapa sawit berbasis web pada KUD di Kab. Dharmasraya. Metode penelitian dalam pembuatan aplikasi menggunakan pengambilan data melalui wawancara dan observasi lapangan langsung, sampel diambil menggunakan purposive sampling dan data adalah berupa foto dan dokumen. Aplikasi dibangun dengan menggunakan Hypertext Preprocesor (PHP), Adobe Flex dan My SQL sebagai yang digunakan untuk data base. Proses penjualan kelapa sawit diawali di tingkat petani atau di kebun, kemudian dibawa ke KUD untuk selanjutnya dilakukan penimbangan ke pabrik dan setelah itu dilakukan pencairan uang di KUD. Aplikasi yang dibuat dapat memangkas waktu dan jarak, memberikan data yang lebih akurat dan informasi harga yang lebih baik, dengan demikian petani dapat meningkatkan pendapatan dan kesejahteraannya karena proses transaksi yang lebih akurat dan transparan.
\end{abstract}

Kata Kunci : sistem penjualan, kelapa sawit, bisnis.

\section{PENDAHULUAN}

Era globalisasi yang melanda dunia secara nyata menyebabkan bermunculan berbagai norma dan aturan baru yang satu sama lain saling tergantung dan kadang - kadang tidak terpisahkan. saling ketergantungan antar negara dicirikan dengan semakin terbukanya pasar dalam negeri terhadap produk - produk negara lain. Perubahan kondisi perdagangan dunia menyebabkan semakin ketatnya persaingan antar unit - unit bisnis di masing-masing negara untuk merebut pangsa pas ar global yang semakin terbuka[1].

Keterbukaan informasi tidak terlepas dari peran berbagai macam teknologi salah satunya teknologi komputer khususnya internet. Internet bukanlah suatu hal yang baru lagi karena sudah men jadi trend dan kebutuhan di dalam masyarakat.
Ke mampuan ko mputer saat ini tidak hanya mampu melakukan pengolahan data atau hitung - hitungan saja namun sudah beranjak menjadi suatu alat komunikasi yang dapat menghubungkan orang yang berada sangat jauh[2]. Sistem jaringan komputer dan internet yang dapat menghubungkan seluruh komputer di berbagai pelosok dunia, dengan kemudahan yang ditawarkan internet maka banyak masyarakat yang menggunakan jasa internet sebagai sarana melakukan transaksi bisnis yang mendatangkan keuntungan secara ekonomi [2]. Sektor pertanian merupakan salah satu sektor yang strategis dalam pelaksanaan pembangunan nasional karena didukung oleh ketersediaan potensi sumber daya alam yang sangat baik dan beragam. Namun demikian, ketersediaan berbagai sumber daya hayati yang banyak tidak menjamin kondisi ekonomi masyarakat akan lebih baik, kecuali bilamana keunggulan tersebut dapat dikelola secara professional, berkelanjutan dan amanah, sehingga keunggulan komparatif (comparative advantage) akan dapat diubah menjadi keunggulan kompetitif (competitive advantage) yang menghasilkan nilai tambah (value added) yang lebih besar.

Kelapa sawit merupakan salah satu tanaman perkebunan yang mempunyai peranan penting bagi sub sektor perkebunan. Pengembangan kelapa sawit antara lain memberi manfaat dalam peningkatan pendapatan petani dan masyarakat, produksi yang menjadi bahan baku industri pengolahan yang menciptakan nilai tambah di dalam negeri, eksport CPO (Cloud Palm Oil) yang menghasilkan devisa. Dari sisi upaya pelestarian lingkungan hidup, tanaman kelapa sawit merupakan tanaman tahunan yang berbentuk pohon (tree crops) yang dapat berperan dalam penyerapan efek gas rumah kaca seperti $\left(\mathrm{CO}_{2}\right)$ dan mampu menghasilkan $\mathrm{O}_{2}$ atau jasa lingkungan lainnya seperti konservasi biodiversity atau ekowisata. Selain itu tanaman kelapa sawit juga menjadi sumber pangan dan gizi utama dalam menu penduduk negeri, sehingga 
kelangkaannya di pasar domestik berpengaruh sangat nyata dalam perkembangan ekonomi dan kesejahteraan masyarakat[3].

Penelitian ini fokus pada pembuatan aplikasi penjualan kelapa sawit berbasis $W E B$ pada KUD di Kabupaten Dharmasraya. Aplikasi ini dibangun dengan menggunakan bahasa pemrograman PHP dan Adobe Flex sebagai alat bantu untuk mendisain dan antarmuka situs web, serta MySQL sebagai basis data. Perancangan system informasi yang digunakan adalah model UML (Unifield Modeling Language). Penelitian ini bertujuan untuk memberikan gambaran tentang bagaimana proses penjualan kelapa sawit di tingkat petani dan membuat suatu aplikasi tentang sistem penjualan kelapa sawit di tingkat petani.

\section{TINJAUAN PUSTAKA}

\section{A. Kelapa Sawit}

Kelapa sawit adalah tanaman perkebunan/ industri berupa pohon batang lurus dari famili Palmae. Tanaman tropis ini dikenal sebagai penghasil minyak sayur yang berasal dari A merika. Brazil dipercaya sebagai tempat pertama kali kelapa sawit tumbuh. Dari tempat asalnya, tanaman ini menyebar ke Afrika, Amerika Equatorial, Asia Tenggara, dan Pasifik Se latan[4].

Benih kelapa sawit pertama kali yang ditanam di Indonesia pada tahun 1984 berasal dari Mauritius, Afrika. Perkebunan kelapa sawit pertama dibangun di Tanahitam, Hulu Sumatera Utara oleh Schadt (Jerman) pada tahun 1911[4].

\section{B. Minyak Kelapa Sawit}

Minyak kelapa sawit diperoleh dari pengolahan buah kelapa sawit (Elaeis guinensis $J A C Q)$. Secara garis besar buah kelapa sawit terdiri dari serabut buah (pericarp) dan inti (kernel). Serabut buah kelapa sawit terdiri dari tiga lapis yaitu lapisan luar atau kulit buah yang disebut pericarp, lapisan sebelah dalam disebut mesocarp atau pulp dan lapisan paling dalam disebut endocarp [5].

Inti kelapa sawit terdiri dari lapisan kulit biji (testa), endosperm dan embrio. Mesocarp mengandung kadar minyak rata-rata sebanyak $56 \%$, inti (kernel) mengandung minyak sebesar $44 \%$, dan endocarp tidak mengandung minyak. Minyak kelapa sawit seperti umumnya minyak nabati lainnya adalah merupakan senyawa yang tidak larut dalam air, sedangkan komponen penyusunnya yang utama adalah trigliserida dan nontrigliserida [6].

\section{World Wide Web (WWW)}

World Wide Web (WWW) dikenal dengan sebutan web, merupakan salah satu layanan yang didapat oleh pemakai komputer yang tergabung ke internet dengan menggunakan teknologi hypertext. Pengguna dapat menemukan informasi yang diperlukan untuk menemukan informasi dengan mengikuti link yang disediakan dalam dokumen web yang ditamp ilkan pada browser web [7].

Internet identik dengan web, karena kepopuleran web sebagai standar interface pada layanan-layanan yang ada di internet. Sebagai penyedia informasi, digunakan juga untuk komunikasi dari email, chatting dan melakukan transaksi bisnis (commerse)[7].

\section{Browser Web}

Browser web adalah software yang digunakan untuk menampilkan informasi dari server web, browser web telah dikembangkan dengan menggunakan user interface grafis, sehingga pengguna dapat melakukan "point dan click" untuk berpindah antar dokumen [7].

Lynux adalah browser web yang masih menggunakan mode teks, sehingga tidak ada gambar yang dapat ditampilkan. Lynux terdapat di DOS (disk operating system) dan *.nix (sistem operasi UNIX). Perke mbangan dari browser mode teks ini tidak seperti browser web dengan GUI (graphic user interface)[7].

\section{E. Server Web}

Server web adalah ko mputer yang digunakan untuk menyimpan dokumen-dokumen web, server web akan melayani permintaan dokumen web dari client-nya. Browser web seperti IE (Internet Explorer) atau Opera, berkomunikasi melalui jaringan (termasuk jaringan internet) dengan server web [7].

Menggunakan HTTP, browser akan mengirimkan request kepada server untuk meminta dokumen tertentu atau layanan lain yang disediakan oleh server. Server memberikan dokumen atau layanannya jika tersedia, dengan menggunakan protokol HTTP[7].

\section{F. Website Dinamis dan Statis}

Web statis adalah website yang berisi informasi-informasi yang bersifat statis (tetap) dan dibangun dengan menggunakan HTML dalam perancangannya. Web Statis yang diutamakan adalah sisi tampilan yang mengandung grafis, sehingga untuk merancang web statis tidak diperlukan kemampuan desain grafis dan cita rasa seni.

Web dinamis adalah website yang terdapat interaksi dari pengguna, terdapat interaksi pada website. Pada website terdapat pemrograman dan unsur data base, sehingga peng-update-an akan lebih mudah dan dapat dilakukan secara realtime atau online. Contoh website dinamis yang diminati adalah facebook. Web dapat dibuat dengan 
menggunakan server side script dan client side script, web master lebih menggunakan server side script karena script dieksekusi di server dan dapat mengakses environment seperti data base [7].

\section{G. Client Side dan Server Side}

Client Side adalah jenis scriptyang dikelola oleh client dengan cara web server akan mengirimkan file tersebut utuh dengan script didalamnya tanpa harus dikelola terlebih dahulu. Contoh dari client side adalah javascript. Server side adalah jenis script yang harus dikelola terlebih dahulu pada server dan akan mengirimkan hasil pengolahan script ters ebut dalam bentuk HTML[7].

\section{H. Hypertext Markup Language (HTML)}

HTML singkatan dari Hyper Text Markup Language, dokumen HTML adalah file text murni yang dapat dibuat dengan editor text. Dokumen in $\mathrm{i}$ dikenal sebagai web page, dokumen HTML merupakan dokumen yang disajikan dalam browser web server. Dokumen ini umumnya berisi informasi ataupun interface aplikasi di dalamnya contohnya notepad, dapat juga dengan web editor misalnya Microsoft Front Page atau dengan Macromedia Dreamweaver.

\section{Unified Modelling Language (UML)}

Notasi UML dibuat sebagai kolaborasi dari Grady Booch, DR. James Rumbough, Ivar Jacobson, Rebecca Wirfs-Brock, Peter Yourdon, dan lainnya[8]. Jacobson menulis tentang pendefinisian persyaratan-persyaratan sistem yang disebut use case. Juga mengembangkan sebuah metode untuk perancangan sistem yang disebut Object-Oriented Software Enginering (OOSE) yang berfokus pada analisis. Booch, Ru mbough dan Jacobson biasa disebut dengan tiga sekawan (tree amigos). Semuanya bekerja diRational software corporation dan berfokus pada standarisasi dan perbaikan ulang UML. Simbol UML mirip dengan Booch, notasi OMT, dan juga ada kemiripan dengan notasi yang lainnya[8].

\section{METODE PENELITIAN}

Penelitian ini bersifat observasi dengan pendekatan melihat efektifitas dan efisiensi dari pelaksanaan panen tandan buah segar kelapa sawit. Data yang digunakan dalam penelitian ini adalah data primer yang diperoleh dengan metode survei dengan wawancara langsung ke lapangan. Survei juga mengamati langsung fenomena yang terjadi di lapangan (perkebunan).

\section{A. Rancangan Alur Penelitian}

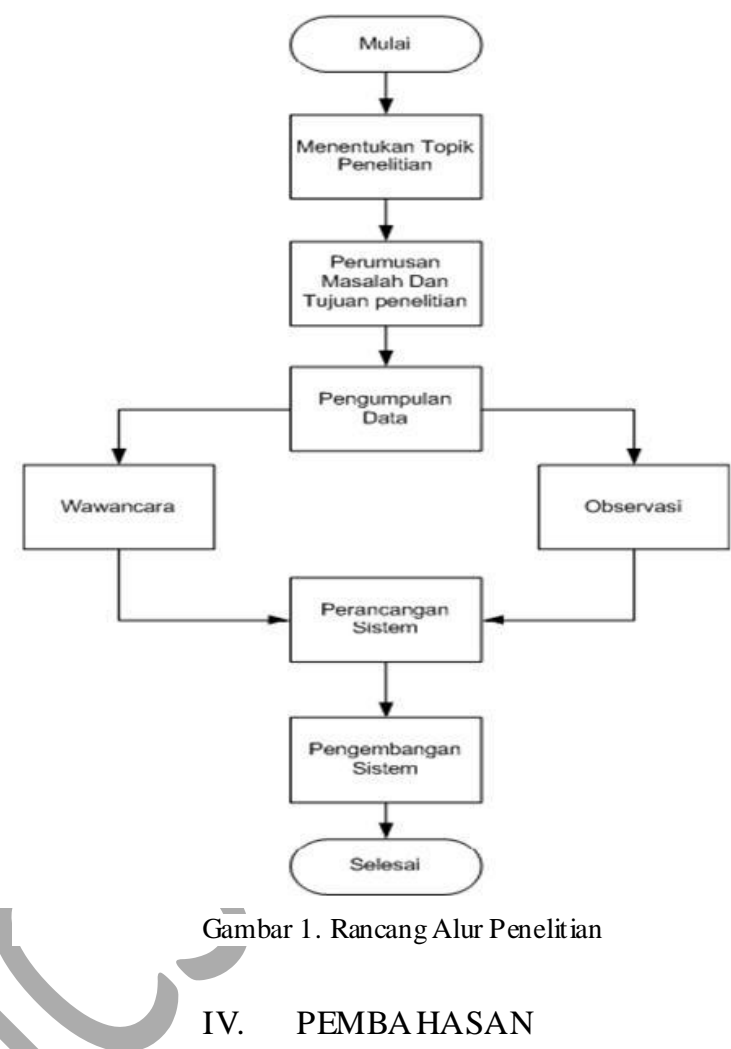

Domain merupakan lingkungan nyata ketika sebuah masalah datang. Model terdiri dari objekobjek yang berinteraksi dengan mengirim pesan satu sama lain. Objek memiliki hal-hal yang diketahui (attribute) dan hal-hal yang dapat dilakukan (behaviour atau operation). Nilai dari atribut-atribut sebuah objek digambarkan dalam bentuk state. Class merupakan 'blueprints' dari objek. Class membungkus atribut-atribut (data) dan behaviour (method dan fungsi) dalam sebuah entiti tunggal yang jelas.

Pada implementasi aplikasi ini terdapat beberapa halangan, diantaranya belum maksimalnya jaringan internet yang ada pada lokasi implementasi aplikasi dan dengan terdapat beberapa lokasi penimbangan baru tempat petani menjual hasil panen kelapa sawit. Semua lokasi baru ini, dimiliki oleh perorangan yang mempunyai modal besar dan menetapkan harga tanpa ada regulasi yang mengaturnya. Sedangkan pada koperasi sendiri, masyarakat tidak dapat mempercayai anggota atau karyawan koperasinya, karena terdapat karyawan dan pimpinan koperasi yang berbuat korupsi.

Berimbas dari koperasi yang tidak lagi produktif atau boleh di bilang "hidup segan mati tak mau" sehingga aplikasi yang sudah ada ini tidak dapat di implementasikan lagi karena oleh beberapa alas an tersebut. 
Kelebihan dari aplikasi penjualan kelapa sawit berbasis web ini adalah sebagai sebuah media yang dapat menjadi solusi bagi para petani kelapa sawit dalam melakukan transaksi TBS (Tandan Buah Segar) dan dapat meningkatkan pendapatan petani secara signifikan. Petani dapat langsung mengakses aplikasi melalui browser tanpa me mbutuhkan instalasi pada setiap PC.

Sedangkan, kekurangan yang ditemukan adalah dari segi tampilan yang masih sederhana dan tidak adanya otorisasi dari report data yang ada, sehingga masih butuh otorisasi secara manual dari pihak yang bertanggung jawab.

\section{KESIMPULAN DAN SARN}

Dengan adanya aplikasi penjualan kelapa sawit mampu meningkatkan pendapatan petani, karena waktu dan jarak untuk pengambilan DO(Delivery Order) dapat di pangkas, untuk validasi data akan lebih akurat dan memperoleh info transaksi dan harga TBS (Tandan Buah Segar).

Dari hasil pembuatan sistem penjualan kelapa sawit di tingkat petani yang berbasis web, maka dapat diberikan saran yaitu :

a) Supaya sistem penjualan kelapa sawit ini dapat dimanfaatkan sebaik - baiknya, agar sistem dapat berjalan leb ih efekt if dan efisien.

b) Pihak KUD perlu melakukan pengontrolan dan pengupdatetan dari sistem yang ada agar mendapatkan hasil yang maksimal.

\section{REFERENSI}

[1] Hadiguna, R. A. 2009. Manajemen Rantai Pasok Minyak Sawit Mentah. Journal of Logistics and Supply Chain Management. 15-19.

[2] Josef Bernadi. 2013. Aplikasi Sistem Informasi Penjualan Berbasis Web pada Toko Velg YQ, ComTech: Computer, Mathemat ics and Engineering Applications Vol.4 No.2

[3] Pratama, Hendra. 2010. Manajemen Risiko Dalam Usaha Perkebunan Kelapa Sawit Pt. Sawindo Kencana, Provinsi Bangka Belitung. Bogor.

[4] Suswono. 2013. Target Produksi Perkebunan Kelapa Sawit Rakyat 6 Ton/hektare. (ekonomi.inilah.com, diakses pada tanggal 21 Januari 2013).

[5] Teknologi Budidaya Kelapa Sawit. 2008. Balai Besar Pengkajian dan Pengembangan Teknologi Pertanian Badan Penelitian dan Pengemabangan Pertanian. Seri Buku Inovasi BUN/11/2008.

[6] Nurhida Pasaribu. 2004. Minyak Buah Kelapa Sawit . Jurusan Kimia Fakultas Matematika Dan Ilmu Pengetahuan Alam Universitas Sumatera Utara. Universitas Sumatera Utara.

[7] Thiam Kian Chiew; Karen Renaud. 2015. Estimating web page response time based on server access log. 9th Malaysian Software Engineering Conference (MySEC). Pages: $140-144$

[8] Siti Azreena Mubin; Azrul Hazri Jantan; Rusli Abdullah; Azrina Kamaruddin. 2015. UML-based navigational design approach for modeling complex interactions in web applications. 9th Malaysian Software Engineering Conference (MySEC) .Pages: 60 - 63 